\title{
PROGRAM AKTIVITAS FISIK MANIPULATIF BERBASIS KINESTETIK UNTUK ANAK USIA 6 TAHUN
}

\author{
Bangkit Seandi Taroreh ${ }^{1}$, Made Agus Wijaya ${ }^{2}$ \\ ${ }^{1}$ Program Studi Pendidikan Olahraga, FKIPB, Universitas Bina Darma \\ Palembang, Indonesia \\ ${ }^{2}$ Program Studi Penjaskesrek, Universitas Pendidikan Ganesha, \\ Singaraja, Indonesia
}

e-mail: $\underline{\text { bangkitseanditaroreh@ @inadarma.ac.id, wijaya.madeagus@ undiksha.ac.id }}$

\begin{abstract}
Abstrak
Program aktivitas fisik pada Satuan Pendidikan Anak Usia Dini merupakan salah satu layanan yang diberikan untuk anak khususnya usia 6 tahun. Program aktivitas fisik bertujuan mengembangkan kematangan kinestetik melalui bermain. Hal ini mendorong guru lebih aktif dalam merancang berbagai macam aktivitas motorik. Penelitian ini bertujuan untuk mengembangkan program aktivitas fisik manipulatif berbasis kinestetik untuk anak usia 6 tahun. Menggunakan metode penelitian kuantitatif dengan pendekatan modifikasi model R\&D dari Borg \& Gall yaitu: 1) studi pendahuluan, 2) pengembangan desain, 3) uji coba skala kecil, 4) produk akhir, 5) diseminasi dan publikasi. Subjek penelitian yaitu guru dan anak usia 6 tahun pada satuan pendidikan anak usia dini di Palembang. Pengumpulan data melalui dokumentasi, observasi, dan kuisioner. Analisis data dilakukan secara deskriptif dari data kuantitatif. Hasil penelitian menunjukkan bahwa 1) program aktivitas fisik manipulatif berbasis kinestetik untuk anak usia 6 tahun telah dinyatakan sangat valid pada indikator kesesuaian materi, valid pada indikator kesesuaian tata bahasa dan sangat valid pada indikator kesesuaian karakteristik anak usia 6 tahun oleh ahli, 2) uji efektifitas melalui penilaian guru diperoleh rata-rata 4,46 sehingga sangat efektif digunakan.
\end{abstract}

Kata-kata kunci: program aktivitas fisik, anak usia 6 tahun

\begin{abstract}
The physical activity program at the Early Childhood Education Unit is one of the services provided for children especially those aged 6 years. The physical activity program aims to develop kinesthetic maturity through play. This encourages teachers to be more active in designing various motor activities. This study aims to develop a kinesthetic-based manipulative physical activity program for children aged 6 years. Using a quantitative research method with a modified $R \& D$ model approach from Borg \& Gall, namely: 1) a preliminary study, 2) design development, 3) a small-scale trial, 4) the final product, 5) dissemination and publication. Research subjects are teachers and 6-year-old children in the early childhood education unit in Palembang. Data collection through documentation, observation, and questionnaires. Data analysis was performed descriptively from quantitative data. The results showed that 1) kinesthetic-based manipulative physical activity programs for 6-year-old children have been declared highly valid on material suitability indicators, valid on grammar suitability indicators
\end{abstract}


and very valid on indicators of suitability characteristics of 6-year-old children by experts, 2) effectiveness test through teacher assessments an average of 4.46 is obtained which makes it very effective to use.

Keywords : physical activity program, children aged 6 years.

\section{PENDAHULUAN}

$\begin{array}{ccc}\text { Sistem Keolahragaan } & \text { Nasional } \\ \text { olahraga }\end{array}$ pendidikan diselenggarakan pada proses pendidikan. Olahraga pendidikan dimulai pada usia dini (Kemenpora, 2014:10). Telaah data dilakukan bahwa jumlah anak usia 3-6 tahun di Indonesia tahun 2015 mencapai 19.113.800 anak (Kemdikbud, 2014:1). Potensi jumlah anak usia dini yang begitu besar perlu pemberian pelayanan pendidikan yang tepat. Oleh sebab itu sangat penting peran olahraga pendidikan pada usia dini.

Permendiknas Nomor 58 Tahun 2009 menyebutkan pendidikan anak usia dini merupakan pembinaan kepada anak sejak lahir sampai usia enam tahun yang dilaksanakan melalui pemberian rangsangan pendidikan untuk membantu pertumbuhan dan perkembangan jasmani dan rohani agar anak memiliki kesiapan dalam memasuki pendidikan lebih lanjut. Implementasinya mendorong guru untuk aktif mengembangkan program dalam membantu pertumbuhan dan perkembangan jasmani dan rohani salah satunya melalui program aktivitas fisik.

Aktivitas fisik merupakan istilah yang dipakai untuk menjelaskan gerakan tubuh manusia sebagai hasil kerja otot rangka (Nani Cahyani Sudarsono, 2015:70-76). Banyak indikator pengembangan program aktivitas fisik usia 6 tahun yang dijelaskan para ahli antara lain: James Tangkudung (2012:8) bahwa program multilateral di sekolah meliputi program latihan keterampilan pokok seperti lari/jalan, melompat, melempar, menangkap, berguling, dan menjaga keseimbangan; Istvan Balyi (2013:187) usia 4-6 tahun merupakan tahap active start yaitu belajar gerak dasar, bermain kombinasi berbagai gerak, peningkatan perkembangan fungsi otak, koordinasi, sosial, motorik kasar, emosi, dan imajinasi; Sergio Lara (2005:4) fase umur 4-6 tahun mengembangkan kebiasaan aktivitas fisik yang baik, nyaman yang muncul dari dalam diri sendiri; David L. Gallahue dan John C. Ozmun (2002:46) menjabarkan tahap perkembangan motorik usia 6 tahun memasuki fase gerak dasar sehingga perlu pengayaan gerak lokomotor, non lokomotor dan manipulatif; Depdiknas (2007:5) menjelaskan bahwa dalam menyusun pedoman pembelajaran fisik/motorik memperhatikan kemampuan jasmani pada anak usia dini meliputi pengembangan kekuatan (strenght), daya tahan (endurance), kelincahan (agylity), kelenturan (fleksibility), koordinasi, ketepatan dan keseimbangan; Peraturan Menteri Pendidikan dan Kebudayaan Republik Indonesia Nomor 146 tahun 2014 menjelaskan program fisik-motorik untuk mengembangkan kematangan kinestetik melalui aktivitas bermain.

Berdasarkan analisis kebutuhan pada satuan pendidikan anak usia dini di Palembang diperoleh data sebagai berikut:

1. Dibutuhkan pengembangan program aktivitas fisik khususnya gerak dasar manipulatif sehingga menambah referensi guru.

2. Hambatan yang dihadapai dalam pelaksanaan program aktivitas fisik 
antara lain: 1) sarana dan prasarana, 2) ketersediaan area bermain.

3. Analisis alokasi waktu pembelajaran motorik sebagai berikut: 1) dua kali pertemuan setiap minggu dengan total alokasi waktu 60 menit, 2) 34 kali pertemuan setiap semester dengan total alokasi waktu 1020 menit.

Tujuan penelitian yang dilakukan untuk mengembangkan program aktivitas fisik manipulatif berbasis kinestetik anak usia 6 tahun dan mengetahui hasil uji efektifitas keterlaksanaan.

\section{Kinestetik}

Berdasarkan Peraturan Menteri Pendidikan dan Kebudayaan Republik Indonesia Nomor 146 tahun 2014 menjelaskan program fisik-motorik untuk mengembangkan kematangan kinestetik melalui aktivitas bermain. Indikator penting dalam pembelajaran kematangan kinestetik adalah aktivitas olahraga (Andrew P. Winterstein, 2003:60). Joaqu'ın Dosil (2006:445) menjelaskan melatih sense kinestetik bisa juga dapat dilatih dengan cara fokus pada tempo/irama (melakukan gerak secara lambat, gerak sesuai irama maupun gerak yang cepat).

Definisi kinestetik yang diungkapkan oleh ahli berbeda-beda antara lain William $\mathrm{H}$ Edward (2011:76) mendefinisikan kinestetik bahwa "kinesthesis: Sense of position and movement of the body and limbs and of external forces acting on the body" yang artinya kinestetik merupakan rasa akan posisi gerakan tubuh, anggota badan dan kekuatan eksternal yang bekerja pada tubuh. Sebagian besar indera manusia tergantung pada stimulasi dari luar tubuh. Sebagai contoh mata, hidung, telinga, kulit dan reseptor pengecap menerima stimulasi eksternal. Namun indera kinestetik berbeda dengan kelima indera yang telah disebut terlebih dahulu, rasa kinestetik tergantung pada stimulasi internal. Ujung syaraf yang disebut spendless atau proprioseptor yang terletak di dalam otot, tendo dan ligamenta, merupakan alat mengkoordinasikan gerakan tubuh. Adapun reseptor labyrinthine yang terletak di bagian dalam telinga adalah pengatur keseimbangan tubuh. Reseptor labyrinthine diaktifkan oleh adanya perubahan posisi atau gerakan kepala yang berkaitan dengan gerakan tubuh secara keseluruhan. Ketika stimulasi eksternal menerpa tubuh maka diperlukan kemampuan membentuk sikap tubuh yang baik atau mempertahankan posisi yang benar. Kemampuan koordinasi dan keseimbangan, keduanya merupakan elemen penting indera kinestetik.

Pendapat lain Vern Gambetta (2007:241) menjelaskan "kinesthetic differentiation is the ability to feel tension in movement and, based on that, to achieve the desired movement" yaitu kemampuan untuk merasakan gerak untuk mencapai gerakan yang diinginkan. Sedangkan Schmidt (2011:46) menjelaskan kinestetik mengacu kepada kumpulan informasi sensori dari tubuh tentang posisi sendi, gerakan, ketegangan dan orientasi ruang.

Tingkat sensitivitas kinestetik ditentukan oleh kemampuan motorik dan hampir setiap orang memiliki tingkat sensitivitas kinestetik berbedabeda. Sensitivitas kinestetik maksimal seseorang mencapai puncak pada usia 12 tahun namun jika ada penurunan sensitivitas kinestesik secara bertahap pada tahun selanjutnya tidak menimbulkan masalah nyata terhadap performa gerak sehari-hari dengan cara selalu memelihara gaya hidup aktif (William H Edward, 2011:77-78). 
Kinestetik berfungsi melalui mekanisme perseptual. Ketajaman perseptual kinestetik mampu memberikan berbagai kemungkinan dalam membuat penyesuaian posisi dan gerakan tubuh yang benar. Pengembangan persepsi motorik menggambarkan proses peningkatan keterampilan gerak. Proses terjadinya perseptual motorik melewati beberapa tahapan antara lain:

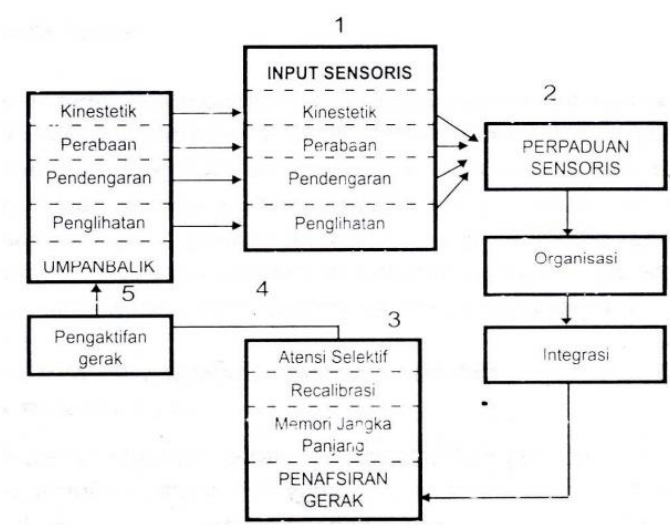

Gambar 1. Proses Terjadinya Perseptual Motorik.

1. Sensory input: receiving various forms of stimulation by way of specialized sensory receptors (visual, auditory, tactile and kinesthetic receptors) and transmitting this stimulation to the brain in the form of a pattern of neural energy.

2. Sensory integration: organizing incoming sensory stimuli and integrating it with past or stored information (memory)

3. Motor interpretation: making internal motor decisions (recalibration) based on the combination of sensory (present) and long-term memory (past) information

4. Movement activation: executing the movement (observable act)

5. Feedback: evaluating the movement by way of the various sensory modalities (visual, auditory, tactile and kinesthetic receptors), which in turn feed information back into the sensory input aspect of the process, thus beginning the cycle again

Menurut David L. Gallahue dan John C. Ozmun (2002:46) menjelaskan karakteristik anak usia 4-6 tahun berada pada fase gerak dasar. Tahapan perkembangan motorik anak ini dimulai dari fase gerakan reflektif, kemudian fase gerakan dasar awal, dimana gerakan dasar pada masa ini masih belum sempurna. Usia dari lahir sampai 1 tahun (refleks) dan usia 1-2 tahun (pra-awal). Selanjutnya fase gerakan dasar terjadi pada usia 2-3 tahun (tahap awal fase gerakan dasar), usia 4-5 tahun (tahap dasar fase gerakan dasar), dan usia 6-7 tahun (fase gerakan dasar tahap dewasa). Dijelaskan lebih lanjut gerak dasar terdiri atas 1) kemampuan lokomotor, 2) kemampuan non lokomotor/stability, dan 3) kemampuan manipulatif.

Sesuai pendapat ahli diatas dapat disimpulkan kinestetik anak usia 6 tahun pada artikel ini adalah rasa gerak terhadap posisi tubuh, orientasi ruang dan keseimbangan tubuh melalui aktivitas fisik gerak dasar khususnya gerak dasar manipulatif. Pentingnya kinestetik pada program aktivitas fisik sebagai salah satu sumber informasi umpan balik (feedback) atas kebenaran gerak yang ditampilkan

\section{METODE}

Metode penelitian menggunakan metode kuantitatif dengan pendekatan modifikasi model R\&D dari Borg \& Gall yaitu: 1) studi pendahuluan, 2) pengembangan desain, 3) uji coba skala kecil, 4) produk akhir, 5) diseminasi dan publikasi. Subjek penelitian terdiri dari 1 ahli, 3 guru dan 15 anak usia 6 tahun. Jenis data yang dikumpulkan berupa data kuantitatif melalui obsevasi dan 
pengisian kuisioner. Analisis data dilakukan secara deskriptif kuantitatif. Data kuantitatif diperoleh dari hasil validasi ahli aktivitas jasmani berdasarkan skala Likert (interval 1-5) seperti pada tabel berikut:

Tabel 1. Skor Validasi Ahli

\begin{tabular}{cc}
\hline Skor & Kriteria \\
\hline 5 & Sangat Setuju \\
4 & Setuju \\
3 & Cukup Setuju \\
2 & Kurang Setuju \\
1 & Sangat Kurang Setuju \\
\hline
\end{tabular}

dianalisis berikut ini:

Hasil kuesioner kemudian

a. Mencari rata-rata perolehan skor setiap indikator dengan rumus: $\bar{x}=\frac{\sum_{i=1}^{n} x_{i}}{n}$

Keterangan:

$\bar{x}=$ rata-rata skor

$$
\begin{aligned}
& x_{i}=\text { skor ke }-\mathrm{i} \\
& n=\text { banyaknya keterangan } \\
& \text { pertanyaan }
\end{aligned}
$$

b. Skor rata-rata tersebut kemudian dikonversikan menjadi data kualitatif berdasarkan kriteria penilaian skala 5 .

Tabel 2. Pedoman Konversi Skor Kualitatif

\begin{tabular}{lc}
\hline \multicolumn{1}{c}{ Interval } & Kriteria \\
\hline $\bar{x}>\bar{x}_{\mathrm{i}}+1,8 S b_{\mathrm{i}}$ & Sangat Baik \\
$\mathrm{X}_{\mathrm{i}}+0,6 S b_{\mathrm{i}}<\bar{x} \leq \overline{\mathrm{x}}_{\mathrm{i}}+1,8 S b_{\mathrm{i}}$ & Baik \\
$\mathrm{X}_{\mathrm{i}}-0,6 S b_{\mathrm{i}}<\bar{x} \leq \overline{\mathrm{x}}_{\mathrm{i}}+0,6 S b_{\mathrm{i}}$ & Cukup Baik \\
$\mathrm{X}_{\mathrm{i}}-1,8 S b_{\mathrm{i}}<\bar{x} \leq \overline{\mathrm{x}}_{\mathrm{i}}-0,6 S b_{\mathrm{i}}$ & Kurang \\
& Baik \\
$\bar{x} \leq \overline{\mathrm{x}}_{\mathrm{i}}-1,8 S b_{\mathrm{i}}$ & Sangat \\
& Kurang \\
\hline
\end{tabular}

Berdasarkan tabel 2 hasil validasi ahli dikategorikan menjadi tabel 3 yaitu:

Tabel 3 Interval Kriteria Validasi Ahli

\begin{tabular}{lcl}
\hline \multicolumn{1}{c}{ Rentang Skor } & Kriteria & \multicolumn{1}{c}{ Kevalidan } \\
\hline $\bar{x}>4,2$ & Sangat Baik & Sangat Valid \\
$3,4<\bar{x} \leq 4,2$ & Baik & Valid \\
$2,6<\bar{x} \leq 3,4$ & Cukup Baik & Cukup Valid \\
$1,8<\bar{x} \leq 2,6$ & Kurang Baik & Kurang Valid \\
$\bar{x} \leq 1,8$ & Sangat Kurang & Sangat Kurang \\
& & Valid \\
\hline
\end{tabular}


Kuisioner guru pada uji coba skala kecil bertujuan untuk mengetahui efektifitas keterlaksanaan produk yang dikembangkan. Kuisioner menggunakan lima pilihan jawaban dengan kriteria penilaian sebagai berikut.

Tabel 4. Skala Penilaian Guru pada Uji Coba Skala Kecil

\begin{tabular}{cc}
\hline Kategori & Skor \\
\hline Sangat Setuju & 5 \\
Setuju & 4 \\
Cukup Setuju & 3 \\
Kurang Setuju & 2 \\
Sangat Kurang Setuju & 1 \\
\hline
\end{tabular}

Analisis efektifitas keterlaksanaan produk dilakukan dengan langkahlangkah yang sama dengan analisis validasi produk oleh ahli. Interval kriteria efektifitas sebagai berikut:

Tabel 5. Kriteria Efektivitas

\begin{tabular}{lcc}
\hline \multicolumn{1}{c}{ Rentang Skor } & Kriteria & Efektifitas \\
\hline $\bar{x}>4,2$ & Sangat Setuju & Sangat Efektif \\
$3,4<\bar{x} \leq 4,2$ & Setuju & Efektif \\
$2,6<\bar{x} \leq 3,4$ & Cukup Setuju & Cukup Efektif \\
$1,8<\bar{x} \leq 2,6$ & Kurang Setuju & Kurang Efektif \\
$\bar{x} \leq 1,8$ & Sangat Kurang & Sangat Kurang Efektif \\
& Setuju & \\
& & \\
\hline
\end{tabular}

\section{HASIL DAN PEMBAHASAN}

Hasil penelitian menunjukkan bahwa 10 variasi program aktivitas fisik manipulatif berbasis kinestetik untuk anak usia 6 tahun telah dinyatakan valid oleh ahli dan sangat efektif digunakan. Secara detail dijabarkan sebagai berikut: 1. Pengembangan Desain

Tahap ini dilakukan melalui perencanaan draf awal kemudian dilakukan validasi produk ke 1 ahli aktivitas jasmani. Validasi produk ke ahli bertujuan untuk melihat kesesuaian materi, kesesuaian tata bahasa, kesesuaian model yang dikembangkan dengan karakteristik anak usia 6 tahun. Hasil validasi ahli terangkum pada tabel 6 .

2. Uji coba skala kecil

Pelaksanaan uji coba skala kecil bertujuan untuk melihat keterlaksanaan efektif digunakan. Subjek penelitian pada uji coba skala kecil terdiri dari 3 guru dan 15 anak usia 6 tahun. Adapun hasilnya adalah 1) 10 variasi program aktivitas fisik manipulatif berbasis kinestetik dapat digunakan. Secara detail dijabarkan pada tabel 8,2) Diperoleh masukan atau saran dari guru antara lain: a) operasional pelaksanaan di sekolah perlu pengawasan oleh guru, b) sebelum 
dilakukan guru sebaiknya memberikan contoh terlebih dahulu sampai anak memahami aktivitas fisik yang dilakukan, c) guru segera mungkin memberikan evaluasi jika gerakan anak yang ditampilkan tidak benar, hal ini perlu dilakukan agar anak memahami gerak dasar manipulatif yang benar.
3. Produk akhir

Setelah melakukan uji coba skala kecil kemudian melakukan revisi pada prosedur operasional pelaksanaan. Produk akhir penelitian dapat dilihat pada tabel 7 dan gambar 2 .

Tabel 6. Hasil Validasi Ahli Aktivitas Jasmani

\begin{tabular}{|c|c|c|c|c|c|}
\hline Indikator & $\begin{array}{c}\text { Skor } \\
\text { Yang } \\
\text { Diperoleh } \\
\end{array}$ & $\begin{array}{c}\text { Banyak } \\
\text { Pernyataan } \\
\end{array}$ & $\begin{array}{l}\text { Rata } \\
\text {-rata } \\
\end{array}$ & Kriteria & Keterangan \\
\hline Kesesuaian Materi & 23 & 5 & 4.6 & Sangat Baik & Sangat Valid \\
\hline Kesesuaian Tata Bahasa & 20 & 5 & 4 & Baik & Valid \\
\hline anak usia 6 tahun & 21 & 5 & 4.2 & Sangat Baik & Sangat Valid \\
\hline
\end{tabular}

Tabel 7. Program Aktivitas Fisik Manipulatif Berbasis Kinestetik Untuk Anak Usia 6

\begin{tabular}{clccc}
\hline No. & Variasi Aktivitas Fisik Manipulatif & $\begin{array}{c}\text { Sadar } \\
\text { posisi } \\
\text { tubuh }\end{array}$ & $\begin{array}{c}\text { Orientasi } \\
\text { ruang }\end{array}$ & $\begin{array}{c}\text { Keseim } \\
\text { bangan }\end{array}$ \\
\cline { 3 - 5 } 1. & $\begin{array}{l}\text { Lempar Tangkap Bola Sambil Melewati } \\
\text { Simpai }\end{array}$ & $\mathrm{V}$ & $\mathrm{V}$ & $\mathrm{V}$ \\
\hline 2. & $\begin{array}{l}\text { Memantulkan Bola Balon Menggunakan } \\
\text { Papan Pantul }\end{array}$ & $\mathrm{V}$ & $\mathrm{V}$ & $\mathrm{V}$ \\
\hline 3. & Menangkap Bola Hasil Pantulan ke Tanah & $\mathrm{V}$ & $\mathrm{V}$ & $\mathrm{V}$ \\
\hline 4. & Menendang Bola ke Gawang & $\mathrm{V}$ & $\mathrm{V}$ & $\mathrm{V}$ \\
\hline 5. & Melempar Shuttlecock ke Berbagai Target & $\mathrm{V}$ & $\mathrm{V}$ & $\mathrm{V}$ \\
\hline 6. & Menggiring Bola Melewati Cone & $\mathrm{V}$ & $\mathrm{V}$ & $\mathrm{V}$ \\
\hline 7. & Lempar Tangkap Bola Berpasangan & $\mathrm{V}$ & $\mathrm{V}$ & $\mathrm{V}$ \\
\hline 8. & $\begin{array}{l}\text { Memantulkan Bola Balon Menggunakan } \\
\text { Papan Pantul Berpasangan }\end{array}$ & $\mathrm{V}$ & $\mathrm{V}$ & $\mathrm{V}$ \\
\hline 9. & Passing Bola Berpasangan & $\mathrm{V}$ & $\mathrm{V}$ & $\mathrm{V}$ \\
\hline 10. & Kombinasi Menendang dan Melempar Bola \\
& Bergantian & $\mathrm{V}$ & $\mathrm{V}$ & $\mathrm{V}$ \\
\hline & & & & \\
\hline
\end{tabular}


Tabel 8. Hasil Efektifitas Produk pada Uji Coba Skala Kecil

\begin{tabular}{|c|c|c|c|c|c|c|c|c|c|c|}
\hline \multirow{2}{*}{ Guru } & \multicolumn{5}{|c|}{ Skor Diperoleh Setiap Indikator } & \multirow{2}{*}{$\sum x_{i}$} & \multirow{2}{*}{$N$} & \multirow{2}{*}{$\bar{x}$} & \multirow{2}{*}{ Kriteria } & \multirow{2}{*}{$\begin{array}{l}\text { Efektifi- } \\
\text { tas }\end{array}$} \\
\hline & $\mathbf{I}$ & II & III & IV & $\mathbf{V}$ & & & & & \\
\hline A & 5 & 4 & 4 & 5 & 5 & 23 & 5 & 4.6 & $\begin{array}{l}\text { Sangat } \\
\text { Setuju }\end{array}$ & $\begin{array}{l}\text { Sangat } \\
\text { Efektif }\end{array}$ \\
\hline B & 5 & 4 & 3 & 4 & 5 & 21 & 5 & 4.2 & Setuju & Efektif \\
\hline $\mathrm{C}$ & 3 & 4 & 4 & 4 & 5 & 20 & 5 & 4 & Setuju & Efektif \\
\hline$\sum x_{i}$ & 13 & 12 & 11 & 13 & 15 & 67 & 15 & 4,46 & $\begin{array}{l}\text { Sangat } \\
\text { Setuju }\end{array}$ & $\begin{array}{l}\text { Sangat } \\
\text { Efektif }\end{array}$ \\
\hline$N$ & 3 & 3 & 3 & 3 & 3 & 15 & & & & \\
\hline $\bar{x}$ & 4.3 & 4 & 3.6 & 4.3 & 5 & 4,46 & & & & \\
\hline Kriteria & $\begin{array}{l}\text { Sangat } \\
\text { Setuju }\end{array}$ & Setuju & Setuju & $\begin{array}{l}\text { Sangat } \\
\text { Setuju }\end{array}$ & $\begin{array}{l}\text { Sangat } \\
\text { Setuju }\end{array}$ & $\begin{array}{l}\text { Sangat } \\
\text { Setuju }\end{array}$ & & & & \\
\hline $\begin{array}{c}\text { Efektifi } \\
\text { tas }\end{array}$ & $\begin{array}{l}\text { Sangat } \\
\text { Efektif }\end{array}$ & Efektif & Efektif & $\begin{array}{l}\text { Sangat } \\
\text { Efektif }\end{array}$ & $\begin{array}{l}\text { Sangat } \\
\text { Efektif }\end{array}$ & $\begin{array}{l}\text { Sangat } \\
\text { Efektif }\end{array}$ & & & & \\
\hline
\end{tabular}

Keterangan:

I : Dapat dilaksanakan, II: Memacu keaktifan siswa, III: Menarik,

IV: Tepat untuk anak usia 6 tahun, V: Layak digunakan.

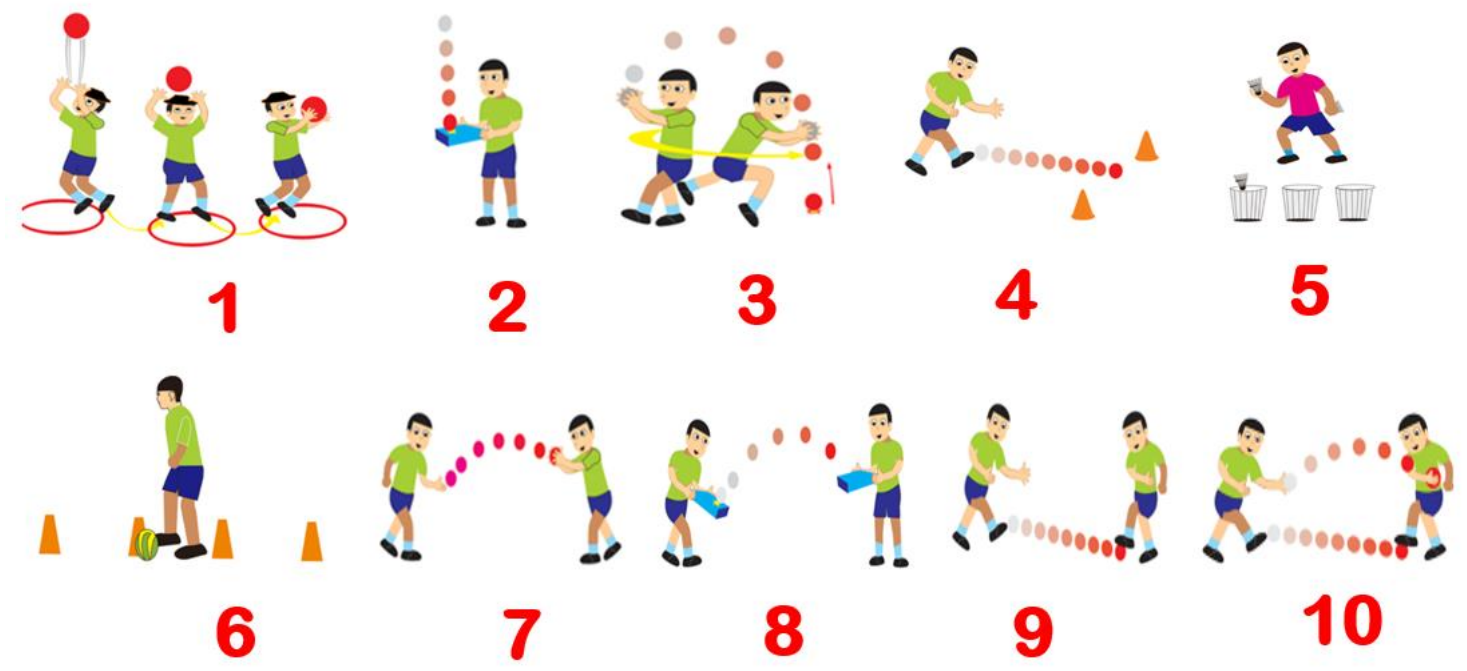

Gambar 2. Program Aktivitas Fisik Manipulatif Berbasis Kinestetik Untuk Anak Usia 6 Tahun

Program aktivitas fisik manipulatif berbasis kinestetik untuk anak usia 6 tahun disusun sesuai kompleksitas gerak dengan mengikuti pola tertentu. Dalam pelaksanaannya guru diberikan kebebasan untuk memilih berbagai variasi aktivitas fisik manipulatif mana yang akan digunakan sehingga tidak terikat harus berurutan.
Hal ini bertujuan agar lebih menarik dan terpenuhi ketercapaian kebutuhan aktivitas anak. Istvan Balyi (2013:192) menjelaskan bahwa anak usia 6 tahun membutuhkan aktivitas fisik bermain aktif minimal 60 menit setiap hari yang tersusun dalam berbagai waktu yang singkat dan terpisah. Sedangkan Danielle D. Wadsworth dkk (2012:391- 
395) lebih detail menjelaskan kebutuhan anak 6 tahun fase aktive start harus terlibat aktif minimal 60 menit aktivitas fisik terstruktur, 60 menit aktivitas fisik tidak terstruktur, dan aktif dalam mengembangkan berbagai keterampilan gerak.

\section{SIMPULAN DAN SARAN}

Penelitian ini dapat disimpulkan bahwa telah menghasilkan program aktivitas fisik manipulatif berbasis kinestetik untuk anak usia 6 tahun yang terdiri dari 10 variasi dan memiliki efektifitas penilaian guru rata-rata 4,46 sehingga sangat efektif digunakan. Hal ini dapat dijadikan sebagai salah satu alternatif program aktivitas fisik manipulatif bagi guru, orang tua maupun masyarakat untuk anak usai 6 tahun di lingkungan sekolah maupun rumah.

Saran untuk penelitian selanjutnya sebaiknya menggunakan sampel yang lebih banyak dengan melaksanakan uji coba skala luas dan melaksanakan Focus Group Discussion (FGD).

\section{DAFTAR PUSTAKA}

Andrew P. Winterstein. 2003. Athletic Training Student Primer A Foundation for Success. USA: SLACK Incorporated.

Borg, Walter R dan Meredith D. Gall. 2007. Educational Research: An Introduction, $4^{\text {th }}$ Edition. New York: Longman Inc.

Danielle D Wadsworth, Leah E. Robinson, Karen Beckham, dan Kip Webster. "Break for Physical Activity: Incorporating ClassroomBased Physical Activity Breaks into Preschools," Early Childhood Education Journal. 2012. Vol. 39, hh. 391-395.
David L Gallahue dan John C. Ozmun. 2002. Understanding Motor Development Infants, Childrens, Adolescents, Adults Fifth Edition. New York: Mc Graw Hill.

Depdiknas. 2007. Pedoman Pembelajaran Bidang Pengembangan Fisik/Motorik Di Taman Kanak-Kanak. Jakarta: Depdiknas.

Dosil, Joaqu'in. 2006. The Sport Psychologist's Handbook a Guide for Sport-Specific Performance Enhancement. England: John Wiley \& Sons Ltd.

Edward, William H. 2011. Motor Learning and Control from Theory to Practice. USA: Wadsworth Cengage Learning.

Gambetta, Vern. 2007. Athletic Development the Art \& Science of Functional Sports Conditioning. USA: Human Kinetics.

Istvan Balyi, Richard Way, dan Colin Higgs. 2013. Long-Term Athlete Development. United States Of America: Human Kinetics.

James Tangkudung dan Wahyuningtyas Puspitorini. 2012. Pelatihan Olahraga Pembinaan Prestasi Olahraga Edisi II. Jakarta: Cerdas Java.

Kemenpora. 2014. Undang-Undang Nomor 3 Tahun 2005 Sistem Keolahragaan Nasional. Jakarta: Kemenpora.

Lara, Sergio. 2005. Coaching for Longterm Athlete Development: Improving Children's Participation and Performance in Sport. New York: Coachwise Limited.

Nani Cahyani Sudarsono, "Indikator Keberhasilan Pengelolaan 
Aktivitas Fisik pada

Penyandang Diabetes Militus

Tipe 2," eJurnal Kedokteran Indonesia, Vol. 3 (1), April 2015.

Peraturan Menteri Pendidikan dan Kebudayaan

Republik
Indonesia Nomor 146 tahun 2014.

Permendiknas Nomor 58 Tahun 2009.

Schmidt, Richard A. 2011. Motor

Learning \& Performance.

Illinois: Human Kinetics. 